\title{
Influence of Porang (Amorphophalus muelleri) Cultivation On The Composition of Soil Arthropods In Tropical Agroforestry Areas In East Java, Indonesia
}

\author{
Amin Setyo Leksono'*, Bagyo Yanuwiadi', Zaenal Kusuma², Akbar Farid ${ }^{1}$, Fujianor Maulana ${ }^{3}$ \\ ${ }^{1}$ Biology Department, Faculty of Mathematic and Natural Sciences, Brawijaya University, Indonesia \\ ${ }^{2}$ Soil Department, Faculty of Agriculture, Brawijaya University, Indonesia \\ 3Postgraduate Program, Brawijaya University, Indonesia
}

\begin{abstract}
This research was conducted on July to October 2010 to evaluate the effect of porang cultivation on the abundance, diversity and composition of soil Arthropods. Change in the abundance, diversity and composition of soil Arthropods was observed using pitfall traps in two study sites (Jember and Madiun). In each study site, samplings were performed in porang cultivation land and non-porang area. A total of 15 traps were put in three lines at each location. The differences in the abundance and diversity were analyzed by using multivariate analyze tests. The soil Arthropod compositions in all locations were compared with Bray-Curtis similarity index. The effect of environmental factors on the arthropod compositions was analyzed using multiple regression. The result showed that the effect of porang-cultivation was not consistent in two study sites. In Madiun, the abundance of soil Arthropods in porang cultivation land was slightly higher than that in non-porang, while the diversity was significantly higer in the former location. In contrast the those in Jember was found in vice versa situation. This study indicate that the effect of porang-cultivation was not subtantial to the composition of soil Arthropods. Therefore practice non harmful porang cultivation should be promoted as a part of agroforestry sistem in both study sites.
\end{abstract}

Keywords: Agroforestry, conservation, pitfall traps Soil Arthropods composition

\section{Introduction}

Concerns about the responses of grounddwelling Arthropods to the human activities such as cultivation, urbanization and silviculture practice have been reported in several studies $[1,2,3,4,5]$. Many of these studies were performed in a temperate region, and only few were reported from tropical region collection $[6,7]$.

The uses of pitfall traps in studying the distribution and composition of teresterial Arthropods have been performed in tropical forests. This is a convenient method to sample soil Arthropods [6,8]. An intensive sampling gives information about the effect of porang (Amorphopalus muelleri) cultivation in agroforestry system to the abundance, diversity and composition of soil Arthropods.

Habitat destruction and fragmentation, introduced species and afforestation are major problems in tropical region. These problems seem to have serious impact on Arthropod

*Corresponding address:

Amin Setyo Leksono

Biology Department, Faculty of Mathematic and Sciences, Brawijaya University

Jl. Veteran, Malang, JawaTimur. Indonesia 65146

Phone : +62-341-575841

Email : amin28@brawijaya.ac.id communities and diversity $[9,10]$. East Java is located in equatorial tropics where examples of rapid destruction of forest occurred even in mountainous areas $[7,11,12]$. In this area, community dynamic of teresterial Arthropods has not been studied in association with cultivation practice.

There are several government programs to solve forest destruction problems particularly in association with local people development. Based on this sceme, local people involved in the management of agroforestry system based on porang cultivation. There is an evidence that cultivation of porang helps prevent illegal logging and the occurrence of forest fire [13]. However the impact of this cultivation to the soil Arthropods community has not been studied. This study intent to evaluate the effect of porang cultivation on the abundance, diversity and composition of soil Arthropods in two study sites in East Java.

\section{Materials and Methods}

The study was carried out in two study sites. First site located in Madiun a hilly land in East Java $\left(7^{\circ} 43^{\prime} \mathrm{S}, 111^{\circ} 37^{\prime} \mathrm{E}, 350 \mathrm{~m}\right.$ in altitude). The area is an agroforestry system based on Enterolobium sp. plant as a canopy trees and 
porang cultivation in forest floor. Second site located in Jember $\left(8^{\circ} 06^{\prime} \mathrm{S}\right.$; $113^{\circ}, 90^{\prime} \mathrm{E}, 400 \mathrm{~m}$ in altitude). The area is cultivated standing trees of Paraserientes falcataria combine with porang cultivation in understorey.

In each study site, samplings were established in two location porang cultivation land and nonporang area. Soil Arthropods were collected during the wet season in July - October 2010 using pitfall traps. At each site, a total of 15 traps ( 5 by 3 rows) were placed systematicaly at $4-\mathrm{m}$ intervals [6]. Glass cups $(10 \mathrm{~cm}$ in diameter and $7 \mathrm{~cm}$ deep) were burried in the ground. The traps was filled with $100 \mathrm{ml}$ formalin solution (4\%) mixed with a few drops of detergent was put into the cup for preservation of collected soil Arthropods. The insects collected from each sampling unit were sorted into families based on Borror et al. [14].

Soil samples were collected twice in each location. Edaphyc factors were measured as follows: $\mathrm{C}$ organic, $\mathrm{N}$ total, $\mathrm{C} / \mathrm{N}$ ratio, organic total and calcium concentration.

The differences in the abundance and diversity were analyzed by using multivariate analyze tests. The soil Arthropod compositions in all locations were compared with Bray-Curtis similarity index followed by UPGMA clustering. The effect of environmental factors on the arthropod compositions was analyzed using multiple regression.

\section{RESULTS}

Our study did not indicated the significant effects of porang cultivation on the abundance and family richness of soil Arthropods. This studi showed that the abundance of soil Arthropods was highest in non-porang land in Jember, where canopy trees were more diverse and tree diameters were lowest. This location comprised various native woody plants such as Paraserientes falcataria, Swietenia mahogany, Mangifera indica.

\begin{tabular}{|c|c|c|c|c|}
\hline \multirow[t]{2}{*}{ Var iable } & \multicolumn{2}{|c|}{ Madiun } & \multicolumn{2}{|c|}{ Jember } \\
\hline & Porang & Non-porang & Porang & Non-porang \\
\hline Canopy tree species & $\begin{array}{l}\text { Enterolobiun } \\
\text { cyclocarpum }\end{array}$ & Enterolobiun cyclocarpum & $\begin{array}{l}\text { Paraserientes } \\
\text { falcataria }\end{array}$ & $\begin{array}{l}\text { Paraserientes } \\
\text { falcataria, Swietenia } \\
\text { mahogany, Mangifera } \\
\text { indica }\end{array}$ \\
\hline Vegetation cover (\%) & $93.75 \pm 5.24$ & $97.5 \pm 10.04$ & $94.5 \pm 6.55$ & $89.5 \pm 6.55$ \\
\hline $\begin{array}{l}\text { Shrubs } \\
\text { Trees }\end{array}$ & $82.43 \pm 8.29$ & $68.25 \pm 4.91$ & $26.25 \pm 6.87$ & $26.25 \pm 6.87$ \\
\hline $\begin{array}{l}\text { Distance between } \\
\text { trees (m) }\end{array}$ & $5.71 \pm 0.76$ & $1.54 \pm 0.73$ & $3.98 \pm 2.21$ & $3.47 \pm 1.89$ \\
\hline Tree diameters $(\mathrm{cm})$ & 48 & 30,3 & 34.7 & 27.3 \\
\hline Shrub species & $\begin{array}{l}\text { Amaranthus } \\
\text { spinosus, Urena } \\
\text { lobata, Ocimum sp., } \\
\text { Blumea sp., and } \\
\text { Commelina } \\
\text { benghalensis }\end{array}$ & $\begin{array}{l}\text { Amaranthus spinosus, } \\
\text { Urena lobata, Ocimum } \\
\text { sp., Blumea sp., and } \\
\text { Commelina benghalensis }\end{array}$ & $\begin{array}{l}\text { Cyatbula prostrata, } \\
\text { Eleusine indica, } \\
\text { Euphorbia dentata, } \\
\text { Isotoma longiflora, } \\
\text { Heliotropium } \\
\text { indicum, } \\
\text { Mikania micrantha }\end{array}$ & \\
\hline
\end{tabular}

\section{Variation on soil Arthropod abundance and diversity}

The effect of porang cultivation to the abundance of soild Arthropods were not consistent between study sites. In Madiun porang cultivation supported the high number of inviduals of soil Arthropods. The number of individual collected from porang cultivation land was higer (3190) than those in non-porang land (2661) (Table 2). Those in Jember was found in vice versa situation. The number of individual collected from porang cultivation land was lower (4227) than those in non-porang land (5878) (Table 3). 
Formicidae dominated the samples both collected in Madiun and Jember. In Madiun, the proportion of Formicidae was $75.5 \%$ followed by Gryllidae (7\%), Lepidoptera larvae (7\%), Aranaeidae (3\%) and Cylisticidae (1.2\%) (Table 2).

Table 2. Soil Arthropod abundance in porang cultivation site and non-porang site in Madiun

\begin{tabular}{lrrr}
\hline Family & Porang & $\begin{array}{r}\text { Non- } \\
\text { porang }\end{array}$ & $\begin{array}{r}\text { Number } \\
\text { of }\end{array}$ \\
\hline Formicidae & 2638 & 1779 & 4417 \\
Acrididae & 201 & 209 & 410 \\
Larva & & & \\
Lepidoptera & 120 & 289 & 409 \\
Araneidae & 82 & 96 & 178 \\
Cylisticidae & 17 & 52 & 69 \\
Coccinellidae & 8 & 57 & 65 \\
Xiphydriidae & 31 & 22 & 53 \\
Oxyopidae & 7 & 44 & 50 \\
Rhinotermitidae & 10 & 20 & 30 \\
Pisauridae & 7 & 22 & 29 \\
Miscellenies & 69 & 70 & 139 \\
\hline Total & 3190 & 2661 & 5851 \\
\hline
\end{tabular}

In Jember, the proportion of Formicidae was $74.8 \%$ followed by Collembola (17.6\%), Staphylinidae (1.8\%), Grillidae (1.7\%), Lycosidae (1.7\%), dan Oxyopidae $(0.8 \%)$ (Table 3 ).

Table 3. Soil Arthropod abundance in porang cultivation site and non-porang site in Jember

\begin{tabular}{lrrr}
\hline Family & Porang & $\begin{array}{r}\text { Non- } \\
\text { porang }\end{array}$ & $\begin{array}{r}\text { Number } \\
\text { indivduals }\end{array}$ \\
\hline Formicidae & 3011 & 4545 & 7556 \\
Collembola & 835 & 950 & 1785 \\
Staphylinidae & 78 & 100 & 178 \\
Grylidae & 75 & 99 & 174 \\
Lycosidae & 96 & 73 & 169 \\
Oxyopidae & 44 & 38 & 82 \\
Linyphiidae & 9 & 12 & 21 \\
Drosophilidae & 11 & 8 & 19 \\
Carcinophoridae & 11 & 6 & 17 \\
Aranaeidae & 8 & 4 & 12 \\
Miscellenies & 49 & 43 & 91 \\
\hline Total & 4227 & 5878 & 10105 \\
\hline
\end{tabular}

Domination of a family (Formicidae) caused diversity level of soil Arthropods in both sites very low $(<1)$. Mean of soil Arthropod diversity in Madiun was higher in non-porang land $(0,47$ $+0,03)$ than those found in porang cultivation $(0,37+0,03)$. Statistical analysis showed that this was signifacantly different $(\mathrm{F}=6.444, \mathrm{P}<0,05)$ (Table 4).

Furthermore, the effect of site was not significant to the number of individual of soil Arthropods. At family level, sampling time had significantly affected to the variation of Coccinellidae abundance $(\mathrm{F}=3,496 ; \mathrm{P}<0,05)$. This was higher in early sampling than in late sampling.

In Jember, mean of soil Arthropod diversity in non-porang land was lower $(0,41+0,05)$ than those found in porang cultivation $(0,44+0,04)$. Statistical analysis showed this was not signifacant $(\mathrm{P}>0,05)$ (Table 5).

Tabel 4. Summary of $\mathrm{F}$ values followed by degree of significance using analysis of variance (ANOVAs) General Linear Model of the abundance of several soil Arthropod families in Madiun $(\mathrm{N}=20$ )

\begin{tabular}{lrrr} 
Taxa & $\begin{array}{c}\text { Location } \\
(\mathrm{a}) \\
\mathrm{df}=1\end{array}$ & $\begin{array}{c}\text { Sampling } \\
\text { time }(\mathrm{b}) \\
\mathrm{df}=3\end{array}$ & $\begin{array}{c}\text { Interaction } \\
(\mathrm{a} \mathrm{x} \mathrm{b)} \\
\mathrm{df}=3\end{array}$ \\
\hline Larva & .001 & 1.069 & .906 \\
Lepidoptera & .396 & .559 & .611 \\
Araneidae & .196 & $3.496^{*}$ & .354 \\
Coccinellidae & 1.497 & .847 & .620 \\
Cylisticidae & .062 & .221 & .727 \\
Gryllacrididae & .039 & .192 & 1.342 \\
Oxyopidae & .009 & .670 & 1.330 \\
Pisauridae & 1.865 & .522 & 1.407 \\
Rhinotermitidae & .431 & 1.233 & .383 \\
Xiphydriidae & $6.444 *$ & 1.303 & 2.539 \\
\hline Diversity & .094 & .152 & .302 \\
Abundance & & &
\end{tabular}

Sampling time had a significant effect to many groups. Overall, the number of individual and diversity were varies among samping time The number of individual several families showed a variation among sampling time such as Formicidae $(\mathrm{F}=7.880, \mathrm{P}<0.001)$, Gryllidae $(\mathrm{F}=$ 9.218, $\quad \mathrm{P}<0.001), \quad$ Lycosidae $(\mathrm{F}=10.531$, $\mathrm{P}<0.001)$, and Staphilinidae $(\mathrm{F}=10.531$ $\mathrm{P}<0.001$ ). (Table 5). In combination with the effect of site, Colelembola showed a high variation in abundance along a use of land related with season (Table 5). 
Tabel 5. Summary of $F$ values followed by degree of significance using analysis of variance (ANOVAs) General Linear Model of the abundance of several soil Arthropod families in Jember $(\mathrm{N}=20)$

\begin{tabular}{cccc}
\hline Taxa & Location & Sampling & Interaction \\
& $(\mathrm{a})$ & time $(\mathrm{b})$ & $(\mathrm{a} \times \mathrm{b})$ \\
& $\mathrm{df}=1$ & $\mathrm{df}=3$ & $\mathrm{df}=3$ \\
\hline
\end{tabular}

\begin{tabular}{lrrr} 
Aranaeidae & .399 & 1.444 & 1.022 \\
Carcinophoridae & 1.903 & .699 & .699 \\
Collembola & .002 & 2.556 & $5.750^{* *}$ \\
Drosophilidae & .890 & .327 & .119 \\
Formicidae & .190 & $7.880^{* * *}$ & .147 \\
Grylidae & 3.434 & $9.218^{* * *}$ & .245 \\
Linyphiidae & .262 & 2.486 & 1.248 \\
& .193 & $10.531^{* *}$ & .531 \\
Lycosidae & .579 & 2.557 & .852 \\
Oxyopidae & .855 & $6.507^{* * *}$ & 1.386 \\
Staphylinidae & .277 & $3.282^{*}$ & .264 \\
\hline Diversity & 1.092 & $6.218^{* *}$ & 1.214 \\
Abundance & &
\end{tabular}

Result of the UPGMA cluster analysis showed that soil Arthropods assemblages were clustered according to their site (Figure 1). Family similarity was greater between the soil arthropod composition in porang cultivation land and non-porang land in Jember than between both sites in Madiun. Branching soil arthropod composition in porang cultivation land and non-porang land in Jember occurred at 82.4.5\%, while that between two sites in Madiun occurred at $78.4 \%$ (Figure 1).

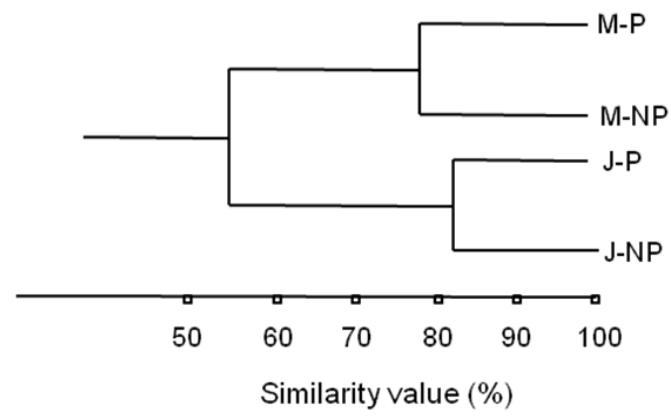

Figure 1. Dendogram showing the UPGMA cluster for the similarity of soil Arthropod assemblages based on BrayCurtis similarity indices (\%). M-P = Porang cultivation in Madiun, $\mathrm{M}-\mathrm{NP}=$ non-porang land in Madiun, $\mathrm{J}-\mathrm{P}=$ Porang cultivation in Jember dan J-NP $=$ Non-porang land Jember

Soil Arthropod composition in all study sites was dominated by soil decomposer. In Madiun, proportion of soil decomposer was higher in porang cultivation $(57 \%)$ than that in nonporang site $(48 \%)$ (Figure 2). Formicidae and
Xiphydriidae were dominated the proportion of soil decomposer guild covering more than $44 \%$ of total samples in porang cultivation site. In contrast, proportion of litter transformer and predator in porang cultivation site was lower than in non-porang site. In the latter site, Lepidopteran larvae and Acrididae were dominatied litter transformer guild covering about $17 \%$ of toal samples, while Aranaeidae and Cylisticidae were dominated predator guild covering covering about $10 \%$ of total samples in non-porang site.

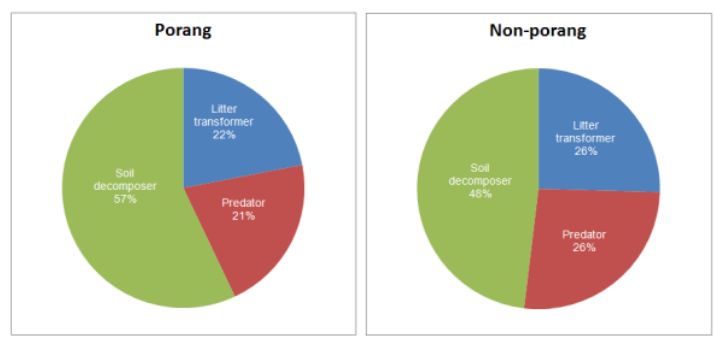

Figure 2. Composition of soil arthropod feeding guilds in porang cultivation site and non-porang site in Madiun

Domination of soil decomposer in Jember was more dramatic than those in Madiun. In this location, proportion of soil decomposer was lower in porang cultivation $(70 \%)$ than that in non-porang site (73\%) (Figure 3). Formicidae and Staphylinidae were dominated the proportion of soil decomposer guild consisting of $46 \%$ of total samples in porang cultivation site and $50.5 \%$ in non-porang site. In contrast, proportion of litter transformer and predator in porang cultivation site was higher than in nonporang site. In porang cultivation site, Gryllidae and Bostrichidae were dominatied litter transformer guild covering about $8.1 \%$ of toal samples in porang cultivation site and $8 \%$ in non-porang, while Lycosidae and Oxyopidae were dominated predator guild covering covering of $10.4 \%$ of total samples in porang cultivation site and $9.3 \%$ in non-porang site.

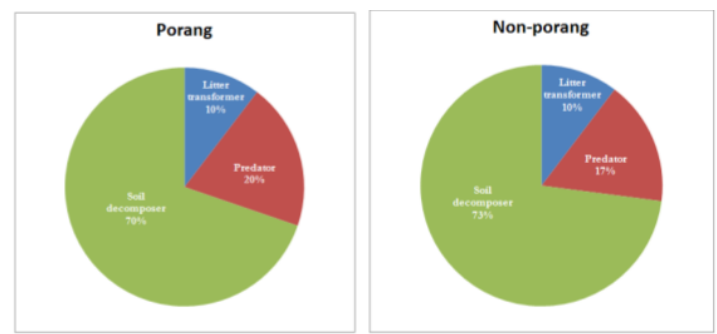

Figure 3. Composition of soil arthropod feeding guilds in porang cultivation site and non-porang site in Jember 
Interaction soil Arthropod abundance and diversity with edaphyc factor

In overall, soil Arthropod abundance has positive correlation with the $\mathrm{C}$ organic, $\mathrm{N}$ total, $\mathrm{C} / \mathrm{N}$ ratio, organic total and calcium concentration (Figure 4a). The similar situation was occurred in the correlation of soil Arthropod diversity with edaphyc factor except calcium concentration

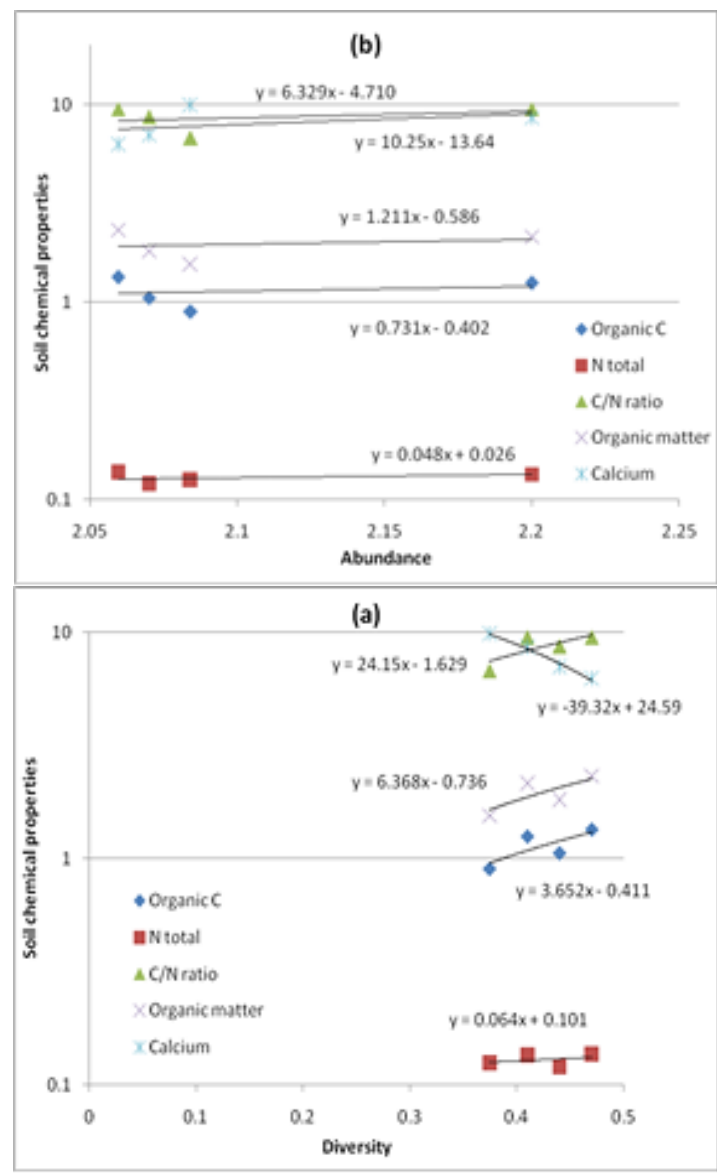

Figure 4. Correlation of soil Arthropod (a) abundance and (b) diversity to severals soil chemical properties (edaphic factors)s

\section{Discussion}

Our study indicated that the effect of porang cultivation to the abundant and diversity was not consistent. The cultivation of porang increase the abundant in a location but decrease in the other. Furthermore the effect of porang cultivation to soil Arthropod diversity was substantial in Madiun. Decreasing diversity of soil Arthropods in this site may associate with the high number of Formicidae. Dominasi Formicidae has reported in some studies of soil Arthropods [3,6]. Some of the studies carried out in farm land anjd secondary forest [7]. Domination of a few taxa such as Formicidae in both study sites lead the divesity of soil arthropod at low level $\left(H^{\prime}<1\right)$. It seem that the abundance of Formicidae in the highly-disturbed responsible for this situation. Similarly, Watt et al. (1997) found that the number of individual leaf-litter Formicidae was greater in sites where there had been partial mechanical clearance (removal of most understorey and $50 \%$ of the canopy).

Among the soil Arthropod groups, the variation in the abundant in both sudy site was not significant. The effect of sampling time was significant to Coccinellidae. Several beetle showed to have seasonal pattern in the abundance such as Carabidae and Brachinidae. This fluctuation might be associated with rainfall [6].

The composition of soil Arthropod assemblages in porang cultivation and non porang site did not differ substantially. Interestingly, that in Madiun differed distinctly from that in Jember.

In all study sites soil decomposer such as Formicidae, Staphylinidae and Rinotermitidae was dominant. This situation indicate a better process of decomposition in soil system. Many studies reported that abundance, species richness and diversity of Arthropods were higher in a site consisting varies of plants [1].

The site with high diversity of plant supports more Arthropod than less diverse [9]. Generally, convertion of forest into cultivation land lead to the decreasing of Arthropods diversity, but the abundance is raising especially foliage fagus $[7,12]$. Intensive agriculture and urbanisation in general change the composition of soil beetle (Carabidae) and spider [1]. In this case, intensive agriculture had change the natural land use into monoculture cultivation followed by application of chemical pesticide and fertilizer.

In this study the effect porang cropping practice in agroforestry system is not substantial because the cultivation of was not followed by plant diversity eradication. Farmer used to keep the diversity of those covering plants. A regular mowing is conducted indeed, but this performed unfrequenly to raise the diversity of shrubs and grasses.

\section{Conclusion}

This study indicate that the effect of porangcultivation was not subtantial to the composition of soil Arthropods. Therefore practice non harmful porang cultivation should be promoted as a part of agroforestry sistem in both study sites. 


\section{Acknowledgement}

The author would like to thank to Director of Directorate of Resarch and Public Service, Directorate General of Higher Education, Ministry of National Education. This research is supported by IMHERE program. We indebt to Dean of Faculty of Mathematic and natual Science, Head of Department of Biology, Head of Perum Perhutani II, Jawa Timur.

\section{Reference}

[1] Allaruika, D. Kotze DJ. Matveinen, K \& Niemnela, 2000. J. Carabid beetle and spider assemblages along a forested urban-rural gradient in southern Finland.

[2] Holland and Christina J.M. Reynolds. The impact of soil cultivation on arthropod (Coleoptera and Araneae) emergence on arable land. Pedobiologia 2003 47 (2): 181-191

[3] Yi H, Moldenke A. Response o Ground-Dwelling Arthropods to Different Thinning Intensities in Young Douglas Fir Forests of Western Oregon. Environmental Entomology . (2005) 34:5, 1071-1080

[4] Stamps W'T, Erik A. Nelson EA, Linit MJ, Survey of Diversity and Abundance of Ground-dwelling Arthropods in a Black Walnut-forage Alley-cropped System in the Mid-western United States. Journal of the Kansas Entomological Society 2009 82(1):46-62.

[5] Schowalter TD, Zhang YL., and Rykken J.J. Litter Invertebrate Responses to Variable Density Thinning in Western Washington Forest Ecological Applications 2010. 13:1204-1211

[6] Sota, T., Nakano, S., Hasan, N., Hasyim A., Syafril and Nakamura, K., 2001, Fluctuation in the Abundance of Terresterial Arthropods at an Arable
Field in West Sumatran Highland. Tropics, pp 463 472.

[7] Leksono, A. S., Penatagama Z. dan Rahardi, b. Pemetaan vegetasi pepohonan dan serangga kanopi di kawasan konservasi sekitar desa Ranupani, Kab. Lumajang. Jurnal Ilmu-Imu Hayati 2008.

[8] Baars M A. Catches in pitfall traps in relation to mean densities of carabid beetles. Oecologia 1979 41:25-46

[9] Chey, VK., Holloway, JD., Hambler, C., \& Speight, MR. 1998. Canopy knockdown of arthropods in exotic plantation and natural forest in Sabah, northeast Borneo, using A., and K. E. insecticidal mistblowing. Bulletin of Entomological Research 88: 15-24.

[10] Floren, A. \& Linsenmair, K.E. 2003. How do beetle assemblages respond to anthropogenic disturbance? In Basset, Y., Novotny, V., Miller, S.E., \& Kitching, R.L. (eds.) Arthropods of Tropical Forests, pp. 190-197. Cambridge University Press, Cambridge.

[11] Abdulhadi R., Srijanto A. \& Kartawinata K. 1998. Forest Biodiversity Research, Monitoring dan Modelling: Conceptual Background and Old World Case Studies. Unesco, Paris and The Parthenon Publ. New York.

[12] Leksono, A.S., Nakagoshi, N. and Isagi, Y. 2005. The effect of forest disturbance on flying insect assemblages in Trawas, East Java. Tropics 14: 335-343.

[13] Santoso E, Sugiyama N, Hikosaka S, Kawabata S. Cultivation of Amorphophallus muelleri Blume in Timber Forests of East Java, Indonesia. Japanese Journal of Tropical Agriculture 2003 47: 190-197

[14] Borror D, Triplehorn C, and Johnson N. An Introduction to the Study of Insects. Harcourt College1989. 